\title{
Pengaruh Komitmen Organisasi dan Peran Manajer Pengelola Keuangan Daerah terhadap Kinerja Manajerial Satuan Kerja Perangkat Daerah di Kota Manado
}

\author{
Leydi Pandelaki \\ Agus. T. Poputra
}

\begin{abstract}
Implementation of performance-based budgeting in government agencies in Indonesia, proclaimed through the enactment of Law No. 17 Year 2003 on State Finance and implemented in stages beginning in the budget 2005.Reformasi financial management resulted in a fundamental change in the financial management of the country / region. The research was conducted at the Regional Working Units Manado City Government. The study population was an employee who worked in Manado City Government on education. Samples were three and four echelons as the authorized users of government budget on education in the city of Manado. Officials in the city of Manado worked as secretary department / agency, department secretary, the head section, sub-section chief, the head of the field, sub-field head and section head who is considered able to describe the performance of each regional secretaries, departments and institutions as a whole technical area. This study aimed to determine the effect of organizational commitment and the role of manager of financial management on the performance of managerial work unit. Collecting data using primary data collection, namely the questionnaire by using purposive sampling technique. Samples were obtained from three-and four-echelon employees who work in regional work units Manado City Government who has served as secretary of the department / agency, the head section, sub-section chief, the head of the field, sub-field head and section head. Data analysis using SPSS software with five stages.First, descriptive statistics.The second phase, testing the quality of the data.The third phase, to test the assumptions of classical aberrations. The fourth stage, performing multiple regression analysis.And fifth stages, testing the hypothesis.

The results showed that organizational commitment and significant positive effect on the performance of managerial work unit. While the role of manager of financial management has no effect and no significant effect on work unit performance.
\end{abstract}

Key Words: organizational commitment 


\section{PENDAhuluan}

\subsection{Alasan Pemilihan Judul}

Pengelolan keuangan daerah secara keseluruhan/kegiatan yang meliputi perencanaan, pelaksanaan, dan penatausahaan, pelaporan, pertanggungjawaban dan pengawasan keuangan daerah. BerdasarkanUU 23 tahun 2004 pasal 66 ayat 1, keuangan daerah harus dapat dikelolah dengan tertib, taat pada peraturan perundang-undangan, efisiensi, ekonomis, efektif, transparan dan bertanggungjawab dengan memperhatikan keadilan, kepatuhan, dan manfaat untuk masyarakat.

Perubahan mendasar dalam pengelolaan keuangan daerah merupakan wujud dari adanya tuntutan publik terhadap akuntabilitas dan transparansi manajemen pemerintah, salah satunya terkait dengan manajemen keuangan negara maupun daerah. (dikutip oleh Tuasikal, 2007) menegaskan tuntutan publik akan pemerintah yang baik memerlukan adanya perubahan paradigma dan prinsipprinsip manajemen keuangan negara, baik pada tahap penganggaran maupun pertanggungjawaban. Hal ini menandakan perubahan paradigma pengelolaan keuangan daerah merupakan suatu tuntutan yang perluh direspon oleh pemerintah, karena perubahan tersebut mengakibatkan manajemen keuangan daerah menjadi kompleks.Akuntabilitas publik adalah pemberianinformasi dan pengungkapan seluruh aktivitas dan kerja finansial PemerintahDaerah kepada pihak-pihak yang berkepentingan (dikutip oleh Mardiasmo, 2002).Keterlibatan setiap personel yang kompeten dalam setiap level organisasi dapat mendorong peningkatan organisasi. Keterlibatan/partisipasi secara luas pada dasarnya merupakan proses organisasional, dimana para anggota organisasi yang dalam hal ini adalah manajer ikut serta dan mempunyai pengaruh dalam suatu pembuatan keputusan yang berkepentingan dengan mereka. Partisipasi dalam konteks penyusunan anggaran merupakan proses dimana para individu yang kinerjanya dievaluasi dan memperoleh penghargaan berdasarkan pencapaian anggaran, ikut serta dan mempunyai pengaruh dalam penyusunan anggaran (dikutip oleh brownel dan Mclnnes, 1986).

Kinerja adalah hasil kerja yang dapat dicapai oleh seseorang atau sekelompok orang dalam suatu organisasi dalam suatu organisasi, sesuai dengan wewenang, dan tanggungjawab masing-masing dalam rangka upaya untuk mencapai tujuan organisasi yang bersangkutan secara legal, tidak melanggar hukum dan sesuai dengan moral maupun etika, (dikutip oleh Rahmawati,2009). Jadi kinerja merupakan hal yang peting bagi perusahaan atau organisasi serta pihak dari karyawan itu sendiri.

Kinerja dipengaruhi oleh beberapa faktor baik yang berhubungan dengan lingkungan perusahaan dan organisasi. Komitmen organisasi diperlukan sebagai salah satu indikator kinerja yang optimal. Seseorang yang bergabung dalam organisasi pada sebuah perusahaan dituntut adanya komitmen dalam dirinya. Sebagai definisi yang umum (dikutip oleh rachmawati, 2009) mengartikan komitmen organisasi sebagai sikap yang menunjukkan "loyalitas" karyawan dan proses berkelanjutan sebagai seorang organisasi mengekspresikan perhatian mereka kepada kesuksesan dan kebaikkan organisasinya. Komitmmen mencakup keterlibatan kerja sebagai derajat kemauan untuk menyatukan dirinya dengan pekerjaan, menginvestasikan waktu, kemampuan dan energinya untuk pekerjaan, dan menganggap pekerjaannya sebagai utama dari kehidupannya.

Manajer pengelolaan keuangan daerah merupakan seseorang yang memiliki pengalaman, pengetahuan, dan ketrampilan yang diakui oleh organisasi untuk memimpin, mengatur, mengolah dan mengendalikan serta mengembangkan kegiatan organisasi dalam rangka mencapai tujuan organisasi untuk melakukan kegiatan tertentu, seta memberikan pengawasan dalam hal ini mengenal keuangan daerah.

Perumusan masalah dapat dirumuskan dalam pernyataan penelitian sebagai berikut .

1. Apakah Komitmen Organisasional berpengaruh terhadap Kinerja Manajerial Satuan Kerja Perangkat Daerah di Kota Manado ?

2. Apakah Peran Manajer Pengelolaan Keuangan Daerah berpengaruh terhadap Kinerja Manajerial Satuan Kerja Perangkat Daerah di Kota Manado ? 
Analisis data melalui lima tahap. pertama statistik deskriptif. Kedua, pengujian kualitas data.Ketiga, melakukan uji penyimpangan asumsi klasik.Keempat, melakukan analisis kuantitatif.Kelima, melakukan uji hipotesis.

\section{LANDASAN TEORI}

\subsection{Akuntansi Keuangan Daerah}

Akuntansi Keuangan Daerah adalah sistem akuntansi yang dipakai oleh Pemerintah Daerahuntuk melakukan manajemen dan pengelolaan keuangan daerah.Manajemen keuangan daerah merupakan alat untuk mengurus dan mengatur rumah tangga Pemerintah Daerah. (dikutip oleh Renyowijoyo, 2008:211).

\subsection{Komitmen Organisasional}

Komitmen organisasional menurut Mathis dan Jackson memberikan definisi, "organizational commitment is the degree to which employees believe in and accept organizational goals an desire to remain with the organizational". (Komitmen organisasional adalah derajat yang mana karyawan percaya dan menerima tujuan-tujuan organisasi dan tetap akan tinggal atau tidak akan meninggalkan organisasi).Komitmen organisasi yang dikemukakan oleh Mowday et. al. ini memiliki ciri-ciri, yaitu: (1). Belief yang kuat serta penerimaan terhadap tujuan dan nilai oragnisasi; (2). Kesiapan untuk bekerja keras; (3). Keinginan yang kuat untuk bertahan dalam organisasi.

\subsection{Peran Manejer Pengelolaan Keuangan Daerah}

Pengelolaan yang berorientasi pada kinerja menuntut adanya desentralisasi.Desentralisasi pengelolaan keuangan daerah merupakan desentralisasi administratif, yaitu pendelegasian wewenang pelaksanaan sampai pada tingkat hirarki yang paling rendah.Dalam hal ini pengelolaan keuangan daerah diberi wewenang dalam batas yang telah ditetapkan dalam sistem pengelolaan keuangan daerah, namun mereka memiliki elemen kebijaksanaan dan kekuasaan serta tanggung jawab tertentu dalam hal sifat dan hakekat jasa dan pelayanann yang menjadi tanggungjawabnya (Coralie dikutip oleh Rohman, 2007).

\subsection{Kinerja Manejerial Satuan Kerja Perangkat Daerah}

Kinerja (performance) menurut Manning dan Curtis (dikutip oleh Rohman, 2009) adalah pencapaian kerja, tindakan, perbuatan, dan lain-lain (accomplishment of work, acts, feat, etc), dalam pengertian lain Manning dan Curtis mendefinisikan kinerja sebagai hasil yang telah dikerjakan (something done or performed).LAN (dikutip oleh Rohman, 2009) mendefinisikan kinerja sebagai gambaran mengenai tingkat pencapaian pelaksanaan suatu kegiatan/kebijaksanaan dalam mewujudkan sasaran, tujuan, misi dan visi organisasi yang tertuang dalam perumusan skema strategis (strategic scheme) suatu organisasi.Secara umum dapat juga dikatakan bahwa kinerja merupakan prestasi yang dapat dicapai organisasi dalam periode tertentu (dikutip oleh Boland dalam Rohman, 2009). Menurut PP Nomor 58 tahun 2005, kinerja adalah keluaran/hasil dari kegiatan/program yang akan atau telah dicapai sehubungan dengan penggunaan anggaran dan kuantitas dan kualitas yang teratur.

\section{Gambaran Umum Responden}

Pengumpulan data pada penelitian ini dilakukan dengan cara mengumpulkan data melalui pengiriman daftar pertanyaan (kuesioner). Pengiriman kuesioner dimulai pada tanggal 25 juni 2012, dengan total kuesioner yang dikirim sebanyak 180. Kuesioner yang kembali sebanyak 120 termasuk 40 kuesioner yang tidak diisi atau diisi tetapi tidak lengkap, sehingga kuesioner yang diolah sebanyak 80 kuesioner.

Adapun rincian jumlah pengiriman kuesioner dan data pengembalian kuesioner dalam penelitian ini ditunjukan pada tabel 4.1 .1 berikut 
Tabel 4.1.1

Rincian Pengembalian Kuesioner

\begin{tabular}{|l|l|l|}
\hline Keterangan & Total & Persentase \\
\hline Kuesioner yang didistribusikan & 180 & $100 \%$ \\
\hline Kuesioner yang tidak kembali & $(60)$ & $33.3 \%$ \\
\hline Kuesioner yang kembali & 120 & $66.7 \%$ \\
\hline $\begin{array}{l}\text { Kuesioner yang gugur (tidak lengkap } \\
\text { pengisiannya) sehingga tidak dapat diolah }\end{array}$ & $(40)$ & $33.3 \%$ \\
\hline Kuesioner yang dapat diolah & 80 & $66.7 \%$ \\
\hline
\end{tabular}

\section{ANALISIS DAN EVALUASI}

\subsection{Deskripsi Data Penelitian}

Dalam tabel 4.2 diketahui bahwa rata-rata (mean) total jumlah skor jawaban untuk variabel Kinerja Manajerial Satuan

Kerja Perangkat Daergah (Y) adalah 18.5375 hal ini menunjukan bahwa rata-rata responden menyatakan Kinerja Manajerial Satuan Kerja Perangkat Daerah dalam unit kerja responden baik.

Dalam tabel 4.2diketahui bahwa rata-rata (mean) total jumlah skor jawaban untuk variabel Komitmen Organisasional $\left(\mathrm{X}_{1}\right)$ adalah 15.1000 hal ini menunjukan bahwa rata-rata responden mengerti dan memahami tentang adanya Komitmen Organisasional dalam unit kerja responden.

Dalam tabel4.2diketahui bahwa rata-rata (mean) total jumlah skor jawaban untuk variabel Peran Manajer Pengelolaan Keuangan Daerah $\left(\mathrm{X}_{2}\right)$ adalah 14.3125 hal ini menunjukan bahwa rata-rata responden menyatakan Peran Manajer Pengelola Keuangan Daerah yang cukup baikmenunjukan kinerja Manajerial yang dicapai.

\subsection{Uji Kualitas Data}

Data utama yang digunakan dalam penelitian ini adalah data primer, dengan kuesioner sebagai alat utama untuk memperoleh data.

\subsubsection{Uji Validitas}

Pada tabel 4.3.1 menunjukkan bahwa hasil uji validitas untuk variable pemahaman komitmen organisasional dengan tujuh butir item pertanyaan, variable peran manajer pengelolan keuangan daeran dengan tujuh butir item pertanyaan, dam variable kinerj Manajerial dengan Sembilan butir item pertanyaan ternyata dinyatakan bahwa semua variable valid karena berada dibawah niali signifikansi $\alpha$ $=0.05$ sehingga butir instrument tersebut dapat digunakan untuk mengukur variable penelitian.

\subsubsection{Uji Reliabilitas}

\begin{tabular}{|l|l|l|l|}
\hline Variabel & $\begin{array}{l}\text { Croanbac } \\
\text { h's Alpha }\end{array}$ & $\begin{array}{l}\text { Stand } \\
\text { ar }\end{array}$ & Keterangan \\
\hline $\begin{array}{l}\text { Komitmen Organisasi } \\
(\mathrm{X} 1)\end{array}$ & 0,717 & 0,6 & Reliabel \\
\hline $\begin{array}{l}\text { Peran Manajerial } \\
\text { Pengelola keuangan } \\
\text { Daerah (X2) }\end{array}$ & 0,872 & 0,6 & Reliabel \\
\hline Kinerja SKPD (Y) & 0,624 & 0,6 & Reliabel \\
\hline
\end{tabular}




\subsection{Uji Asumsi Klasik}

\subsubsection{Uji Multikolinearitas}

Gambar 4.4.3 merupakan hasil uji normalitas dengan menggunakan analisa grafik dan dari Gambar 4.4.3 dapat dilihat bahwa data menyebar di sekitar garis diagonal dan mengikuti arah garis diagonal, maka dapat dikatakan bahwa distribusi data residual normal.

\subsubsection{Hasil Uji Autokorelasi}

Dari Tabel 4.4.4 dapat dilihat bahwa nilai uji Durbin-Watson adalah 2.030 sehingga kesimpulannya tidak dapat disimpulkan terjadi autokorelasi.

\subsection{Pengujian Statistik}

\subsubsection{Analisis Regresi Linear Berganda}

Regresi linear berganda digunakan untuk mengetahui apakah Komitmen Organisasional dan Peran Manajerial Pengelolaan Keuangan Daerah berpengaruh secara serentak terhadap Kinerja Manajerial Satuan Kerja Perangkat Daerah. Model analisis linear berganda yang digunakan untuk menguji hipotesis adalah sebagai berikut .

Analisis Regresi Linear Berganda

$\mathbf{Y}=\boldsymbol{\alpha}+\boldsymbol{\beta}_{1} \mathbf{X}_{1}+\boldsymbol{\beta}_{2} \mathbf{X}_{2}+\boldsymbol{\varepsilon}$

Berdasarkan Tabel 4.5.1 dapat dilihat persamaan regresi linear berganda adalah

$\mathbf{Y}=\boldsymbol{\alpha}+\boldsymbol{\beta}_{1} \mathbf{X}_{1}+\boldsymbol{\beta}_{2} \mathbf{X}_{2}+\varepsilon$

\section{$Y=13.611+0.0425$ KO -104 PMPKD}

\subsubsection{Koefisien Korelasi $(R)$}

Dari Tabel 4.5.2dapat dilihat nilai $\mathrm{R}$ adalah 0,501 yang memberi arti bahwa terdapat hubungan yang cukup kuat antara Komitmen Organisasional dan Peran Manajer Pengelolaan Keuangan Daerah terhadap Kinerja Manajerial Satuan Kerja Perangkat Daerah.

\section{Coefficients $^{\mathrm{a}}$}

\begin{tabular}{|c|c|c|c|c|c|}
\hline \multirow[t]{2}{*}{ Model } & \multicolumn{2}{|c|}{ Unstandardized Coefficients } & Standardized & \multirow[t]{2}{*}{$\mathrm{t}$} & \multirow[t]{2}{*}{ Sig. } \\
\hline & B & Std. Error & Beta & & \\
\hline (Constant) & 13.611 & 1.667 & & 8.164 & .000 \\
\hline $\begin{array}{ll}\text { KOMITMEN } \\
\text { ORGANISASI }\end{array}$ & .425 & .089 & .540 & 4.782 & .000 \\
\hline PKD & -.104 & .125 & -.094 & -.831 & .408 \\
\hline
\end{tabular}

\subsubsection{Koefisien Determinasi $\left(\mathrm{R}^{2}\right)$}

Dari Tabel 4.5.3 dapat dilihat nilai $\mathrm{R}^{2}$ adalah sebesar 0.251 atau 25.1\% sehingga dapat disimpulkan bahwa Kinerja Satuan Kerja Perangkat Daerah (Y) mendapat kontribusi dari Komitmen Organisasional $\left(\mathrm{X}_{1}\right)$ dan Peran Manajer Pengelolaan Keuangan Daerah $\left(\mathrm{X}_{2}\right)$ sebesar 25.1\% sedangkan sisanya $74.9 \%$ mendapat kontribusi dari faktor atau variabel lain yang tidak diteliti dalam penelitian ini.

\subsubsection{Uji t}

3. Pengujian Hipotesis Pertama $\left(\mathrm{H}_{1}\right)$

Dari Tabel 4.5.4, nilai t hitung untuk variabel komitmen Organisasional 4.782 adalah dengan nilai probabilitas signifikansi sebesar 0,000. Karena probabilitas signifikansi lebih kecil dari 0,05 dapat disimpulkan bahwa hipotesis pertama $\left(\mathrm{H}_{1}\right)$ diterima. Hal ini menjelaskan tentang berpengaruh positif antara variabel Komitmen Organisasional terhadap variabel kinerja Manajerial Satuan Kerja Perangkat Daerah. 
4. Pengujian Hipotesis Kedua $\left(\mathrm{H}_{2}\right)$

Dari Tabel 4.5.4, nilai t hitung untuk variabel Peran Manajer pengelolaan Keuangan Daerah adalah -.831 dengan nilai probabilitas signifikansi sebesar 0,405 .

Karena probabilitas signifikansi lebih besar dari 0,05 dapat disimpulkan bahwa hipotesis kedua $\left(\mathrm{H}_{2}\right)$ ditolak. Hal ini menjelaskan tentang pengaruh negative antara variabel Peran Manajer Pengelolaan Keuangan Daerah terhadap Kinerja Manajerial Satuan Kerja Perangkat Daerah.

\subsubsection{Uji F}

Dari uji ANOVA didapat nilai hitung F sebesar 12.909 dengan probabilitas signifikansi 0,000.Probabilitas signifikansi tersebut lebih kecil dari 0.05, maka variabel Komitmen Organisasi dan peran Manajer Pengelolaan Keuangan Daerah secara bersama-sama berpengaruh signifikan terhadap variabel Kinerja Manajerial Satuan Kerja Perangkat Daerah.

\section{Pembahasan}

\subsubsection{Pengaruh Komitmen Organisasi terhadap Kinerja Manajerial Satuan Kerja Perangakat Daerah}

Hasil pengujian hipotesis menunjukkan bahwa pengaruh Komitmen Organisasional terhadap Kinerja Manajer Satuan Kerja Perangkat Daerah berpengaruh sebesar 4.782 pada tingkat signifikansi 0.000, yang berarti signifikan karena berada di bawah nilai signifikansi yang dipersyaratkan yaitu 0.05 , sehingga dapat disimpulkan bahwa komitmen organisasi dapat meningkatkan kinerja pemerintah daerah.

\subsubsection{Pengaruh Peran Manajer Pengelolaan Keuangan Daerah terhadap Kinerja Manajerial Satuan Kerja Perangkat Daerah}

Hasil pengujian hipotesis menunjukkan bahwa pengaruh Peran Manajer Pengelolaan Keuangan Daerah terhadap Kinerja Manajerial Satuan Kerja Perangkat Daerah berpengaruh negative sebesar -.831 pada tingkat signifikansi 0.408 , yang berarti tidak signifikan karena berada di atas nilai signifikan yang dipersyaratkan yaitu 0.05, sehingga dapat disimpulkan bahwa Peran Manajer Pengelolaan Keuangan daerah yang tinggi tidak dapat meningkatkan Kinerja Manajerial Satuan Kerja Perangkat Daerah.

\section{KESIMPULAN DAN SARAN}

\subsection{Kesimpulan}

Berdasarkan hasil analisis data dan pengujian hipotesis dengan menggunakan alat bantu SPSS yang telah diuraikan pada bab sebelumnya, maka diperoleh kesimpulan mengenai Komitmen Organisasional dan Peran Manajer Pengelolaan Keuangan Daerah sebagai berikut

4. Berdasarkan pengujian yang dilakukan secara parsial maka dapat diketahui Komitmen Organisasional berpengaruh terhadap kinerja manajerial SKPD dikarenakan probabilitas signifikansinya lebih kecil dari 0.05 hal ini menjelaskan berpengaruh positif antara variable Komitmet organisasi terhadap variable kinerja manajerial SKPD. Hal ini menunjukan bahwa semakin tingginya Komitmen Organisasional maka semakin tinggi pula kinerja Manajerial Satuan Kerja Perangkat Daerah.

5. Berdasarkan pengujian yang dilakukan secara parsial maka dapat diketahui peran manajer pengelolaan keuangan daerah terhadap kinerja manajerial SKPD dikarenakan probabilitas signifikansinya lebih besar dari 0.05 hal ini menjelaskan berpengaruh negatif antara variableperan manajer pengelolaan keuangan daerah terhadap variable kinerja manajerial SKPD.Peran Manajer Pengelolaan Keuangan Daerah tidak berpengaruh terhadap Kinerja Manajerial Satuan Kerja Perangkat Daerah. Hal ini menunjukan bahwa semakin rendah Peran Manajer Pengelolaan Keuangan Daerah maka akan semakin menurunnya Kinerja Satuan Kerja Perangkat daerah.

6. Akan tetapi tidak dapat dipungkiri bahwa hasil pengujian secara bersama-sama antara variablevariabel bebas terhadap variable terikat, diketahui terdapat hubungan yang cukup kuat antara variable X1 dan X2 terhadap variable $\mathrm{Y}$ secara serentak. Hal ini menunjukan bahwa jika 
pengujian dilakukan bersama-sama maka hal ini menunjukan pengaruh dan hubungan yang cukup terhapan kedua variable tersebut.

\subsection{Saran}

Dengan segala keterbatasan yang telah disebutkan sebelumnya, maka peneliti memberikan saran untuk penelitian selanjutnya, yaitu :

Hasil penelitian menunjukkan bahwa variabel peran komitmen organisasi lebih berpengaruh terhadap kinerja manajerial satuan kerja perangkat dari pada variabel manajer pengelolaan keuangan daerah.Hal ini dikarenakan karena kurangnya pengetahuan atau minimnya pegawai yang menguasai pekerjaan yang sesuai dengan bidang yang digeluti masing-masing pegawai.

\section{DAFTAR PUSTAKA}

Anthony, R. N. dan V. Govindrajan 2005.Sistem Pengendalian Manajemen. Buku 1. Jakarta: Salemba Empat.

Budiharjo, C. 2008. "Analisis Pengaruh Kepuasan Kerja, Kepemimpinan danKomitmen Organisasional terhadap Semangat Kerja Karyawan (Studi padaBalai Latihan Kerja dan Industri Semarang.” Skripsi Tidak Dipublikasikan,Program Sarjana, Universitas Diponegoro Semarang.

Brownel, P. dan McInnes M. 1986. "Budgetary Participation, Motivation, andManagerial Performance”, The Accounting Review, Vol. LXI, No. 4.Milani, K. 1975. " The Relationship of Participation in Budget-Setting toIndustrial Supervisor Performance and Attitudes : A Field Study”, TheAccounting Review 50.

Ghozali, I. 2005. Aplikasi Analisis Multivariate dengan Program SPSS. Semarang: Badan Penerbit Universitas Diponegoro.

Halim, A. dan T. Damayanti. 2007.Akuntansi Sektor Publik :Pengelolaan Keuangan Daerah, Yogyakarta:UPP STIM YKPN.

Herminingsih. 2009. "Pengaruh Partisipasi Anggaran dalam Penganggaran dan Peran Manajerial Pengelola Keuangan Daerah terhadap Kinerja Pemerintah Daerah. Tesis Tidak Dipublikasikan, Program Pasca SarjanaMagister Akuntansi, Universitas Diponegoro Semarang.

Mardiasmo. 2005. Akuntansi Sektor Publik. Yokyakarta : Penerbit Andi.

Mahsun, Mohamad. 2009. Pengukuran Kinerja sector Publik. Yogyakarta : BPFE

Nordiawan dan Hertianti. 2010. Akuntansi sektor Publik. Jakarta : Salemba Empat

Pangastuti, M. D, 2008. "Pengaruh Partisipasi Penganggaran Dan Kejelasan Sasaran Anggaran Terhadap Kinerja Manajemen Pemerintah Daerah Dengan Komitmen Organisasi Sebagai Moderator (Studi pada Kabupaten Timur Tengah Utara).Tesis Tidak Dipublikasikan, Program Pasca SarjanaMagister Akuntansi, Universitas Diponegoro Semarang.

Rachmawati. S. R. 2009. "Pengaruh Komitmen Organisasi, Motivasi Kerja, Dan Gaya Kepemimpinan Terhadap Kinerja Karyawan Bidang Keuangan Pada Pemda Kabupaten Sukoharjo."Skripsi Tidak Dipublikasikan, ProgramSarjana, Universitas Muhammadiyah Surakarta.

Robbins. S. P. 2006. Perilaku Organisasi. Edisi 10 Bahasa Indonesia. Jakarta: PT.INDEKS Gramedia.

Rohman, A. 2007. "Pengaruh Peran Manajerial Pengelola Keuangan Daerah Dan Fungsi Pemeriksaan Intern Terhadap Kinerja Pemerintah Daerah (Survei Pada Pemda Kota, Kabupaten, dan Provinsi di Jawa Tengah).” JurnalMAKSI, Vol. 7, No. 2, pp.206-220

Sekaran, U. 2007. Metodologi Penelitian untuk Bisnis. Jakarta: Penerbit SalembaEmpat.

Tuasikal, A. 2007. "Pengaruh Pemahaman Sistem Akuntansi, Pengelolaan Keuangan Daerah Terhadap Kinerja Satuan Kerja Pemerintah Daerah (Studi pada Kabupaten Maluku Tengah di Provinsi Maluku)." JurnalAkuntansi Dan Keuangan Sektor Publik 